\title{
Consequences of Workplace Stress - Company Case Study
}

\author{
Andrea Bencsik ${ }^{1}$, Tímea Juhász ${ }^{2}$, Ladislav Mura ${ }^{1}$ \\ ${ }^{1}$ J. Selye University, Faculty of Economics; University of Pannonia, Faculty of Business \\ and Economics \\ 2 Budapest Business School, Faculty of International Management and Business
}

\begin{abstract}
The issue of work-related stress has been addressed by researchers for a decade, while less interest in the issue has been shown by company executives. In spite of the known effects of work-related stress, not sufficient attention is devoted to it by the top management. A case study was applied in our research to investigate the stress level of employees and consequences of workplace stress in the chosen company. Our research activity was supported by personal observation, document analysis, interviews and a questionnaire survey. The results show that negative impact of stress on the employee health (calculated economic effect of stress) is significantly higher than the cost of employee training. Creating a pleasant work environment and improving the cooperation of co-workers may result in reduction of sick leave and the employee fluctuation.
\end{abstract}

Keywords: workplace, workplace stress, employees, employee health.

\section{Introduction}

The review of scientific literature shows that stress was an unknown phenomenon 100 years ago both in private life and the world of work. The first records about stress date back to the 1930s, when it was described as physical strain or physical symptoms resulting from overload. Over the years, both physical and psychological overload have become symbolic expressions (Seilerová, 2019), and nowadays we think about stress as mental strain.

What has changed during the years? What is the reason that people are unable or less able to cope with difficulties they face in life? 
The answer can be approached from two different perspectives. Compared to the situation 100 years ago, the world has undergone tremendous changes in economic, social and scientific terms. Due to development, the labour market has undergone significant changes, the family model has changed and masses of women started to work. As a consequence of scientific development and changes in education systems, more and more students are entering higher education and finish their university studies. The life stages of young people have changed since they spend longer time in education. It is acceptable

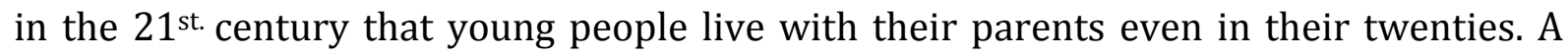
certain ratio of students take up work during their studies, while others do not have interest in that. Changes in lifestyle and shift of different important events in their life is characteristic compared to standards 100 or even 20 and 30 years ago. These trends brought changes in parenting; parents are protecting their children more than before, providing and ensuring everything for children has become their main goal. This is the reason why young people find it difficult to cope with stressful situations and lack coping skills (Klimplová, 2012). Parents have been protecting their children since early childhood, so their children face stressful situations and challenges rarely. They are trying to help their children, quite often by solving the problems their children face. As a result of this fact, young people do not develop the ability to cope with difficulties and stressful situations or it is developed later. Young people face less physical challenge than before, and they are not forced to encounter difficult situations.

As a global reason might be mentioned the busy lifestyle and the conflict of roles (Remi, 2018). Expectations are increasing in different areas of life and it is becoming increasingly difficult to meet them.

The study is examining the occurrence of workplace stress and its impact on employees. The main objective of the case study applied is to explore the most common causes of workplace stress; how employees experience the positive and negative impact of stressful situations; quantifying the consequences of stress and propose specific solutions for the company problems.

\section{Theoretical overview}

\section{The physiological impact of stress}

The concept of stress was first discussed in details by Hans Selye, the Hungarian physician (Selye, 1936; 1956; 1976). He was the first to define stress as „a nonspecific response of the body to any demand", which is the lowest common multiple of an organism's response to any stress it experiences (Cooper, 2000).

The term used by Selye caused confusion in the scientific community, since the term is interpreted in two different ways. One refers to external effects of stress on the organism, while the other refers to changes in human body caused by external factors (Juhász, 2002). Over the past few decades, various definitions of the term had been used that 
contributed to misinterpretation of the term (Le Fevre and Kolt, 2010; Jex, Beehr and Roberts, 1992; Kahn and Byosiere, 1992). The terminology „stress“ has not disappeared from the scientific and everyday use (Briner, Harris and Daniels, 2004).

Kahn and Byosiere (1992) made more suggestion for the use of terminology „stress”, which made the research on stress more transparent.

Our study is based on the most general definition of stress applied by Cropanzano et al. (2005), Juhász (2002), Kahn and Byosiere (1992). According to this definition, stress is an interactive process, when the environmental circumstances and events (stressors) have impact (physical, psychological or social) on the individual. The factor that triggers stress is called a stressor. A stressor can be anything that causes a state of strain or tension and we treat it as a source of stress that generates reaction (Bagdy, 2007). The presence of some factors causes tension and dissatisfaction in almost everyone.

Stress is present in everyone's life and might have different forms. There are basically two types of stress. Eustress is a term used for positive stress, which has positive impact, enhances our performance, exploits hidden energy reserves and has positive impact on our body. Distress refers to negative stress that impairs our performance, makes it difficult to cope with stressful situations and its constant presence can cause serious health problems and illnesses (Bernardi, 2019). It appears as a reaction to stressful life events e.g. heavy workload, financial problems, stressful relationships, death. The fast lifestyle is also contributing to increase of stress. Not everyone can cope with everyday stress. The first symptom might be the fatigue, but in long-term the immune system is affected. Cardiovascular disease, atherosclerosis, hypertension, stomach problems, indigestion, depression and sleep disorders can be the signals of stress. That is why it is important to reduce the level of stress at work and find the appropriate stress management techniques.

Most people are aware of the concept of stress. They can feel, experience and recognize the symptoms of stress, but they feel less informed how to prevent, avoid or combat it. Only few people know which factors influence the risk of developing stress and which are the factors that can reduce the level of stress. In order to provide a focused overview of the issue, we will only deal with work-related stress.

\section{Work-related stress factors}

Since in most of the cases individuals are assessed based on their workplace performance, many people find their daily work stressful due to performance constraints.

The workplace stress models make it possible to capture the characteristics of the work environment and help in the analysis of work-related stress issues. The study highlights the most important sources of work-related stress below.

\section{Person Environment Fit Model}

According to this model, there are two sources of workplace stress. The first is, when the opportunities provided by work cannot meet the motivation and needs of the employee. The other source of stress is when the requirements and the skill-set of the employee are 
not in accordance with the job profile. The requirements include the workload or the complexity of work to be conducted. Tension can arise if the employee does not have the skills to meet the requirements, but also if the skills are beyond the requirements of the job and cannot be appropriately utilized in the position. The disadvantage of this model is that cannot predict the expected occurrence of stress (Salavecz, 2011).

\section{Jobs-Demand Resources Model}

Requirements are considered the psychological stressors present in the work environment e.g. strained work pace, time pressure, demanding work, unclear and contradictory expectations. The control examines, whether the employee has the opportunity to use his or her abilities and skills, can learn new things and utilize his or her creativity. It also controls the decision-making power regarding the work conditions e.g. whether the employee can influence the manner and pace of the tasks he or she has to complete (Karasek, 1979).

Later, a new variable was added to the model: social support at the workplace. The model assumes that the worst health condition is expected when the requirements are high, but the decision-making ability, the employee control and the employee support are low (Salavecz, 2011).

\section{Effort-Reward Imbalance Model}

According to this model, if the effort between the work completed and the reward for this work is imbalanced, the tension caused might result in worsening health condition (Siegrist, 2004).

The effort and reward dimensions measure the factors of work-related stress. These efforts are the time pressure, interruptions, work responsibility, physical effort, overtime and the increasing workplace requirements (Salavecz, 2011).

\section{Workplace injustice}

The theory of workplace injustice highlights the importance of different types of unfair treatment the employee is directly involved. One of its components is related to the company's distribution systems, while the other focuses on the way the company operates. The unfair distribution is closely related to the fairness of the system the employees are rewarded (Moorman, 1991).

It is important how the company managers treat their subordinates, in what measure the employees are involved in decision-making processes, whether the decision-making is free from prejudice (Salavecz, 2011; Novotný, 2014; Kaźmierczyk, Chinalska, 2018).

\section{DRIVE-model of the workplace stress}

The DRIVE-model - „Demand - Resources and Individual Effects-model” presents the main external-organizational and internal-personal factors of the workplace stress (Mark, 2008). The detected level of workplace stress depends on the actual workload, workplace resources, personal factors and the subjective assessment. The interaction of these factors 
and the effect of supporting factors will determine, whether stress will have a long-term effect or not.

Since the success of organizations depends, among other factors, on success, reliability, quantity and quality of the human performance, one of the most important managerial tasks is to provide working conditions that can support the expected performance of the employee both in physical and sociological terms. Ignored stressful situations might have serious consequences on the individual and the organization as well.

\section{The consequences of work-related stress}

The research of British and American scientists highlights that the work-related stress increases the number of days spent on sick leave. The estimated numbers show that stress in the US economy reduces the productivity indicators by tree billion dollars yearly. The main reasons listed are the health insurance costs, the accidents and the replacement of the employee (Ember, 2009). The increased stress level can result in weak performance, increased employee fluctuation, absenteeism and customer dissatisfaction.

The state of emotional exhaustion is often associated with irritability, antipathy, repetitive use of power tools (e.g. punishment) and indifference (Jakab et al, 2006; Fapohunda, 2017). Positive emotions are a key factor in organizational performance and commitment. Understanding the emotions of employees is essential for HRM, since the managerial practices and the organizational environment influences the employee behaviour (Kanten-Sadullah, 2012; Bognár, Bencsik, 2016).

In recent years, many international organizations have raised awareness of psychosocial risks and work-related stress. However, steps ahead have been made in understanding work-related stress; there are still gaps in effective application of knowledge into practice on organizational level. Work-related stress is one of the most commonly reported causes of work-related illnesses, affecting more than 40 million people in the European Union. Reasons include the lack of awareness in the European countries that is often linked to lack of expertise and the appropriate infrastructure. There is a clear need to implement systematic and effective prevention strategies linked to company management practice (Zoni - Lucchini, 2012; Stefko, 2019).

The case study is the most suitable research method for detecting workplace incidents and work-related stress. The theoretical features of case study and its application in the company will be described below.

\section{Research method}

\section{Case study}

The case study is a systematic, well-prepared and methodologically sound observation and data recording method. Observation and interview techniques are mainly applied in case studies. There are four main characteristic features of case studies: openness, communication between the researcher and the participant, naturalness and clarity (Dolnhofer, 2001. p.9.). „The openness of case study means that the researcher does not 
work with pre-defined research questions and methods, but is open to change his or her ideas, questions and tools during the research" (Kormos, 2004. p.26). The interpretative nature of case study stems from the fact that the case described appears „as a world interpreted by the researcher and the researched" (Dolnhofer, 2001. p. 16). The case study can support a theory or hypothesis and helps us draw some general conclusion.

\section{Practical research}

Introduction of the company

The case study as a part of this research was conducted in a small retail shop, selling sport equipment. The worldwide success of the company is due to high-quality own-branded products, tailored to specific sport and sold at affordable price. The R\&D activity serves as a basis to own-brand development. The long-term goal of the company is to operate as a $100 \%$ passion brand. It means to exclude the world known brands from their shelves (approx. 20\%).

Organizational structure: the company is characterized by divisional organizational form. The divisions (21 stores) are organized according to achieved profit and territorial principle. In terms of management, the operational decisions are in the hands of store managers, while the leaders of strategic units are responsible for making strategic decisions.

Organizational culture: The company is proudly committed to core human values. It is looking for future employees considering these values, but also expects these values to be respected by all the employees of the company. These values are the following: honesty, responsibility, altruism, vitality. The pursuit of innovation and focus on the future are also important values.

Competitors and the market: Based on public data available, the company is close to the market leaders, but has to fight for the market leader position on domestic and international market as well.

The issue addressed in case study: The employees are exposed to self-perceived stress at work, and the workplace stress has impact on private life and health of the employees.

In order to provide in-depth investigation to the problem, personal interviews, observation and a questionnaire survey was conducted. The results of the questionnaire survey will be presented below. The questionnaire was accessible online and the respondents used the internal information system of the company to fill in the questionnaire survey. The questionnaire included 19 questions. The questions aimed at identifying stress situations, reactions of respondents to these situations and the consequences. The survey contained closed questions, nominal and metric variables and a 5-point Likert scale was applied. The data analysis methods were the following: frequency and mean tests, correlation, crosstab analysis, independent t-test in SPSS statistics.

The questionnaire survey was not compulsory; the employees were motivated by their managers to participate in the research. $87 \%$ of the staff, 165 employees participated in the survey, working in different stores. 
Demographic data: the questionnaire was completed by $65.5 \%$ of female and $35.5 \%$ male respondents. This ratio reflects the proportion of man and woman working for the company. The average age of the respondents is $18-25 ; 41.2 \%$ of the respondents belong to this group. The ratio of respondents between 25 and 30 is $34.5 \%$. This result reflects the average age of the company employee (27.5\%).

$21.2 \%$ of the respondents completed high school education, while $45.5 \%$ of them had a university degree. $50 \%$ of the female respondents had university or college degree, while this ratio of male respondents reached only $40 \%$.

The survey differentiates 4 types of respondents based on their work position: sales staff, managers, office managers and other. $56 \%$ of the male respondents worked as sales staff compared to $70 \%$ of female respondents in the same position. Managerial position was taken over by $31 \%$ of the male respondents. This ratio was only $22 \%$ with female respondents. The survey has shown that respondents with college or university degree were in managerial positions (50\%), while those with completed secondary education $(89 \%)$ worked as a sales staff. Based on the observation technique and the questionnaire survey applied in our research, the following hypothesis was formulated.

\section{Hypothesis}

The age, gender and job title affect how employees in the company experience workrelated stress.

\section{Results}

After collecting the demographic data of the respondents, the survey questions focused on work-related stress. The stress experienced by the employee can be positive or negative. $64 \%$ of the respondents experience stressful situations negatively, while $36 \%$ experienced stress in a positive way. The analyses show significant difference between the male and female respondents. Less than half of the male respondents (44\%) and $73 \%$ of the female respondents had negative experience with work-related stress. The Chisquare test confirmed the gender difference (Pearson's Chi-square: $15.750 \mathrm{df}: 1$ sign.:.000 $\mathrm{p}<0.05$ ).

The question arises whether there is any relationship between the age of the respondent and the impact of stress. We determined three age groups: respondents under the age 30, respondents between 30 and 40, and the over 40 group. We detected no significant difference between the age groups experiencing stress (Pearson's Chi-square: $3.542 \mathrm{df:} 2$ sign.: 170 p> 0.05). $61 \%$ of the respondents in their twenties, $73 \%$ of the respondents in their thirties and all the respondents in their forties struggle with stress.

There was no significant difference in respondents' perception of stress in terms of their educational background (Pearson Chi-square: .116 df: 3szign.: .990 p> 0.05).

Negative stress experience was detected among the representatives of sales staff $(66 \%)$, while managers had positive stress experience (83\%). Significant correlation with stress 
can also be observed in terms of work position: Pearson's Chi-square: $13.456 \mathrm{df:} 3$ sign.: $.004 \mathrm{p}<0.05$. It can be summarized that the older female employees (sales staff) are more likely to have negative feeling with stressful situations.

Further target of the analysis was how employees feel the work-related stress influences their workplace performance. Most of the respondents (70\%) reported that they have problems with concentration, more than a third of them make mistakes more frequently than in general and almost every second respondent feels more stressed and enters a conflict with colleague. Not only negative, but positive effects were mentioned by the respondents as well. One fifth of the respondents in this study gain energy from stress and almost a third of them perform better under stress.

The research highlighted the stress factors the employees of the company face. The respondents had to use a five-point scale to assess the frequency of stress factors $1=$ never and 5 =always). The following table presents the mean and standard deviation of the stress factors.

Tab. 1: The occurrence of stress factors at workplace

\begin{tabular}{|l|r|r|r|r|}
\hline \multirow{2}{*}{} & \multicolumn{2}{|c|}{ N } & \multicolumn{2}{c|}{$\begin{array}{c}\text { Standard } \\
\text { deviation }\end{array}$} \\
\cline { 2 - 5 } & Valid & \multicolumn{1}{|c|}{ Missing } & \multicolumn{1}{c|}{ Mean } & 1.054 \\
\hline Wime management & 165 & 0 & 2.87 & 1.123 \\
\hline Relationship with colleagues & 165 & 0 & 3.03 & .907 \\
\hline Conformity and making mistakes & 165 & 0 & 1.99 & .999 \\
\hline
\end{tabular}

Source: Own editing.

The results presented in Table 1 show that stressful situations connected to work-life balance is the most frequent. The highest value of standard deviation can be detected in this case, which shows that the respondents did not agree at this point. Stressful situations between the colleagues are the least frequent; the answers provided by the respondents are similar. The study also analyzed the relationship between these variables. A slightly strong correlation can be detected between time management and conformity (Pearson's correlation: r: .391 sign.: .000 p<0.05), similar level of correlation can be detected between time management and the work-life balance (Pearson's correlation: r: .379 sign.: $0.00 \mathrm{p}<0.05$ ). The obtained results are understandable. The less time the employee has to complete the task, the more likely they will make mistakes or experience problems with time management e.g. overtime. These also have impact on work-life balance.

The study examines how male and female respondents are affected by these factors. The results of Independent Samples T-Test are summarized in Table 2. 
Tab. 2: Gender based Independent T-test $(\mathrm{p}=0.05)$

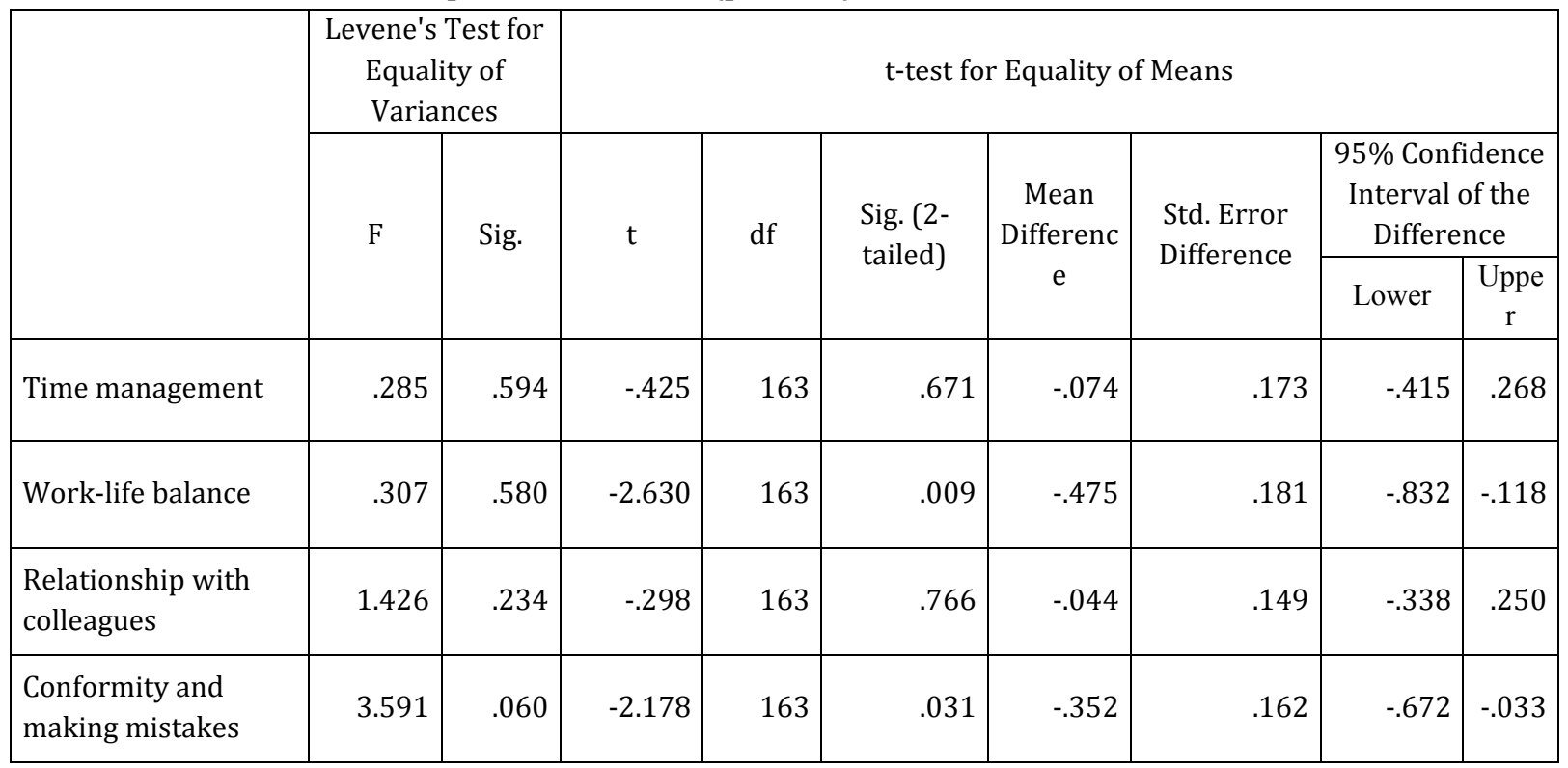

Source: own editing

Based on the results presented in Table 2 we can summarize that in terms of work-life balance and conformity there is difference between the male and female respondents. In both cases, these factors occur more frequently with female respondents.

However, the ANOVA studies have shown that there is no significant difference in terms of the respondent age among the factors. Time management proved to be a problem in managerial positions (average: 3), while workplace conformity factor occurs more frequently with sales staff (average: 2.29). A significant difference can be detected in case of these two factors. 
Tab. 3: ANOVA results $(\mathrm{p}=0.05)$

\begin{tabular}{|c|c|c|c|c|c|c|}
\hline & & $\begin{array}{c}\text { Sum of } \\
\text { Squares }\end{array}$ & $\mathrm{df}$ & $\begin{array}{l}\text { Mean } \\
\text { Square }\end{array}$ & $\mathrm{F}$ & Sig. \\
\hline \multirow[t]{3}{*}{ Time management } & Between Groups & 36.015 & 3 & 12.005 & 13.210 & .000 \\
\hline & Within Groups & 146.313 & 161 & .909 & & \\
\hline & Total & 182.327 & 164 & & & \\
\hline \multirow[t]{3}{*}{ Work-life balance } & Between Groups & 4.575 & 3 & 1.525 & 1.214 & .306 \\
\hline & Within Groups & 202.273 & 161 & 1.256 & & \\
\hline & Total & 206.848 & 164 & & & \\
\hline \multirow{3}{*}{$\begin{array}{l}\text { Relationships with } \\
\text { colleagues }\end{array}$} & Between Groups & .359 & 3 & .120 & .143 & .934 \\
\hline & Within Groups & 134.635 & 161 & .836 & & \\
\hline & Total & 134.994 & 164 & & & \\
\hline \multirow{3}{*}{$\begin{array}{l}\text { Conformity and making } \\
\text { mistakes }\end{array}$} & Between Groups & 8.490 & 3 & 2.830 & 2.934 & .035 \\
\hline & Within Groups & 155.304 & 161 & .965 & & \\
\hline & Total & 163.794 & 164 & & & \\
\hline
\end{tabular}

Source: Own editing.

The results obtained also confirm the presence of the mentioned models above.

Stress has a significant impact on the health of the respondents (average: 3.45 on a fivepoint scale. where $1=$ no impact. 5 =high impact). Stress has higher impact on female respondents (female average: 3.61. male average: 3.19). Most of the respondents can cope with the consequences of stress (64\%). About $66.1 \%$ of the respondents ask for help in dealing with stress. The age, gender and the work position do not make difference between the respondents.

Table 4 presents who is providing help for the respondents in stressful situations. The respondents had to assess whom they ask for help on a five-point scale $(1=$ not characteristic at all. $5=$ absolutely characteristic).

Tab 4: Who do the respondents ask for help?

\begin{tabular}{|l|r|r|}
\hline & Mean & Standard deviation \\
\hline Family member & 4.21 & 1.181 \\
\hline Friend & 4.35 & 1.044 \\
\hline Colleague & 3.34 & 1.239 \\
\hline Superior & 3.33 & 1.364 \\
\hline Professional & 3.05 & 1.510 \\
\hline
\end{tabular}

Source: Own editing.

It can be summarized that respondents ask help from their family members or friends. Incompany stress management is not common. Around 65\% of the surveyed respondents expressed their interest in learning about stress management techniques. 
Finally, the results above also confirm that there is a reason why stressful situations are not handled in the company. $23 \%$ of the respondents think that nobody examines the consequences of stress, while $71 \%$ of the respondents do not even know about this kind of activity.

No stress management data was found during the document analysis of the company, which would support the answer provided by the respondents. However, there is an employee satisfaction survey, so the problem can be indirectly addressed in the questionnaire survey.

\section{DISCUSSION}

The survey conducted in the company revealed that the most dominant stressors in dayto-day work are meeting the requirements, time pressure and maintaining the work-life balance.

The hypothesis was confirmed. The age, gender and work position influence how the respondents experience stress. Based on the answers, the Jobs-Demand Resources Model and the Person Fit Environment Model problems can be identified.

Differences between genders were identified in case of multiple factors, but the results reflect that women feel more uncomfortable in stressful situations. Negative stress has deeper impact on older colleagues.

In terms of position, salespeople are more likely to experience stressful situations, while the executives reported positive impact in the same situations. Concerning health, the respondents had different opinion about the impact of work-related stress on their health in terms of individual ability to cope with stress.

\section{Solution to the problem, proposal}

The results of the analysis and the personal observation show that stress testing and measuring the consequences of stress are not present in the company. The employees rarely address the management with the problem, while direct and indirect effects of stress can be measured in terms of company performance.

In order to provide useful proposals for the management, additional company data was needed, which was obtained through document analysis. Although estimated results of company stress could be obtained, but more evidence is needed to call the attention of company management to address the issue of workplace stress. The data obtained from company documentation can be used to calculate the additional costs of stress-related health problems. The calculations are based on the answer of respondents participating in the survey. $64.2 \%$ of the employees reported that their health problems, and thus their time spent on sick leave and sick pay is closely linked to workplace distress. We also examined the proportion of those employees who considered their illnesses to be related to workplace stress. $35 \%$ of sales staff and 29\% department managers considered their health problems are closely related to workplace stress, while neither of the directors reported clear answer to this question. This ratio was $50 \%$ in case of employees working 
at the headquarters. As we continue to examine the economic impact in terms of different work positions, this set of data is a basis for the following calculations.

The average gross salaries for different positions were considered, while calculating the company cost for a day sick leave. The following table presents the wages on monthly basis.

Tab. 5. Average wages

\begin{tabular}{|l|r|}
\hline \multicolumn{1}{|c|}{ Jobs } & \multicolumn{1}{c|}{ Average wages } \\
\hline Sales staff & $167.946 \mathrm{HUF}$ \\
\hline Department managers & $326.174 \mathrm{HUF}$ \\
\hline Store managers & $650.851 \mathrm{HUF}$ \\
\hline Headquarter employees & $573.404 \mathrm{HUF}$ \\
\hline Average & $\mathbf{4 2 9 . 5 9 4} \mathrm{HUF}$ \\
\hline
\end{tabular}

Source: Own editing.

In addition to costs paid after the colleague on sick leave, the costs of employee replacement were also calculated to get the total cost.

The number of absent hours as a result of sick leave was 9483 hours in 2018, so the average per person was 50 hours a year. If calculations are made on full-time employment basis ( 8 hours a day), it means 6.25 days /employee. An average monthly wage of 429.594 HUF means the following costs for the employer:

- it means 6,25 days sick leave a year, during which the employer is obliged to pay a social contribution, which is $22 \%$ of the gross wage.

- replacing the colleague on sick leave

If calculations are made on basis of 9483 hours of sick leave, the following results are obtained:

- counting with 168 hours, the equivalent of hourly wage will be: 429.594/168=2.557 HUF

- the social contribution paid after 9483 day of sick leave is: (9483*2.557) $* 0,7 * 0.22=3,734,197$ HUF

- the cost of employee replacement in case of 9483 hours is $9483 * 2557=24,248,031$ HUF

- in summary: $3,734,197+24,248,031=27,982,228 \mathrm{HUF}$

The result of final calculation above shows the costs of sick leave for the company on yearly basis. It is an important information, but does not provide detailed data regarding the research. It has to be emphasized that the stress-related diseases do not make up $100 \%$ of the sick leave on annual basis. According to our research results, $43 \%$ of the employees feel that their illness is closely related to workplace stress. If we consider only $43 \%$ of the sum above, we receive a substantial sum of 12 million HUF.

Using Internet resources and price quotations, we can conclude that the sum of 12 million HUF is far more higher than the cost spent on stress management training. It can be said that a 2-day multi-field stress management training designed for companies would cost 60 000-100 $000 \mathrm{HUF} /$ employee. 
Being a sport-related trading company, special attention is paid to the qualification of employees in different kinds of sports. Participation on basic employee training is compulsory, while participation on innovative types of trainings is optional. The company is organizing in-house trainings, where the trainers are employed by the company and provide trainings additionally to their day-to-day activities. The selection of trainers is made possible by the performance evaluation system.

Application for trainings and managing dates of trainings happens with a help of HR software, where the dates of trainings are uploaded by trainers and the employees can apply with the agreement of their supervisor. The level of employee qualification is also tracked with the help of this system as well as the availability of trainings designed for them.

In addition to in-house trainings, if the employee has been working more than five years for the company or more than three years in a higher position, they have a possibility to participate on trainings organized by external experts. These are self-awareness courses, communication or language courses.

\section{Proposal}

An optimal solution can be to select an employee from each department store, who is keen on providing trainings for colleagues and open to addressing different issues, solving problems. Since qualifying trainers have already been successful on other areas, considering the company culture, this should not be a problem either. The company consists of 21 department stores and one headquarter. If we calculate the costs of qualifying 22 trainers, the highest cost of stress management training per capita is 100,00 HUF; calculating the total cost we get 2,200,000 HUF. This cost is much lower than the mentioned 12 million HUF. By providing a stress management training for employees following the probation period, the company would be able to improve its HR indicators e.g. fluctuation that was $37.5 \%$ in 2018 .

\section{Conclusion}

The company management and the employees have already recognized that they are exposed to work-related stress, which has impact on their private life. According to answers provided by the respondents, the biggest stress for the employees is maintaining the work-life balance. As one of the stressors was mentioned the company communication, whether the communication is realized with the headquarters or superiors. The communication is not always clear, direct and open. Employees also reported physical illness as a result of workplace stress.

The data obtained showed that the estimated cost of stress-related sick leave is much higher than the hypothetical cost the company would spend on helping employees to prevent stress or dealing with stressful problems. In addition to cost-efficiency, we proposed a solution that could be fully integrated into the current knowledge 
management system of the company. A smooth implementation of this solution is expected.

The mentioned data shows that all of the successful companies should consider an initiative related to stress prevention and dealing with workplace stress. This step would be important not only to improve the economic performance of the company or reduce costs, but as the new tendencies show, this is the most valuable resource to ensure the performance of human capital and retaining employees in the workplace. Losing valuable workforce and the replacement is one of the biggest challenges the companies face nowadays.

Several previous case studies and the examination of models above demonstrates the relationship between the parameters we have also researched. Fan and Smith (2017) observed railway workers in terms of work-life balance and well-being at work based on the impact of workplace stress. The results showed that the staff who perceived high levels of control and support had a better work-life balance and an increased sense of well-being. A positive personality was associated with positive well-being both at work and outside of work. Williams et al. (2017) used the Demands-Resources- Individual Effects (DRIVE) Model and the Well-Being Process Questionnaire (WPQ) to reveal relationships, where the logistic regression showed that well-being outcomes were predicted by high positive personality and low negative coping. Positive job appraisals were predicted by high resources and low demand. Smith and Smith (2017) investigated the implications of well-being at work, considering the relationship between the individual and the organization. Their research results showed a positive relationship in terms of positive consequences of managerial decisions on their employees Pisanti et al. (2011) detected a similar relationship investigating the job characteristics of Dutch and Italian nurses in relation to organizational conditions vs distress-eustress. Several further studies can be mentioned showing the same result. All of these support our proposal that the managers of organizations should pay emphasized attention on workplace-stress and its consequences.

\section{References}

BAGDY, E., 2007. Pszichofitnessz. Kacagás - kocogás - lazítás. Animula Kiadó, Budapest

BERNARDI, A., 2019. The capability approach and organizational climate as tools to study occupational health and safety. Insights into Regional Development. 1(2), 155-169.

BOGNÁR, T. and BENCSIK, A., 2016. Career crises as a validity factor of prognosis. Acta Oeconomica Universitatis Selye. 5 (2), 19-30.

BRINER, R. B., HARRIS, C. and DANIELS, K., 2004. How do work stress and coping work? Toward a fundamental theoretical reappraisal. British Journal of Guidance and Counselling, 32, 223-234. 
CROPANZANO, R., GOLDMAN, B. M. and LEHMAN, B. III., 2005. Organizational Justice. In: Barling, J., Kelloway E. K. és Frone M. R. (Eds.): Handbook of Work Stress, Sage, London, 63-88.

DOLNHOFER, E., 2001. Az esettanulmány, Budapest 2001.

EMBER, A., 2009. A munkahelyi stressz, mint a leggyakoribb modern foglalkozási megbetegedés. Acta sana: az egészségügyi és a szociális ellátás elmélete és gyakorlata. 4(2), 15-23.

FAN, J. and SMITH, AP., 2017. Positive well-being and work-life balance among UK railway staff. Open Journal of Social Sciences. 5(6), 1-6.

FAPOHUNDA, T. M., 2017. Gender and impression management in the workplace. Acta Oeconomica Universitatis Selye. 6(2), 47-56.

JAKAB, E., NECULAI, K., KOMÁROMI, J. and LÁZÁR, I., 2006. Munkahelyi stresszdiagnózis a munkahelyi stresszmenedzsmentben. Alkalmazott Pszichológia VIII. I, 101-126.

JEX, S., BEEHR, T. and ROBERTS, C., 1992 The meaning of occupational stress items to survey respondents. Journal of Applied Psychology. 77, 623-628.

JUHÁSZ, Á., 2002. Munkahelyi stressz, munkahelyi egészségfejlesztés. Oktatási segédanyag, Munka- és Szervezetpszichológiai Szakképzés, Budapest.

KAHN, R. L. and BYOSIERE, P., 1992. Stress in organizations. In: Dunette, M. D. and Hough, L. M. (Eds.): Handbook of industrial and organizational psychology. Consulting Psychologists Press, Palo Alto. 3, 571-650.

KANTEN, S. and SADULLAH, O., 2012. An empirical research on relationship quality of work li-fe and work engagement. Procedia - Social and Behavioral Sciences. 62,. 360 - 366.

KARASEK, R., 1979. Job Demands, Job Decision Latitude, and Mental Strain: Implications for Job Redesign. Administrative Science Quarterly. 24, 285-308.

KAŹMIERCZYK, J., and CHINALSKA, A., 2018. Flexible forms of employment, an opportunity or a curse for the modern economy? Case study: banks in Poland. Entrepreneurship and Sustainability Issues. 6(2), 782-798.

KLIMPLOVÁ L., 2012. Employers' View on Problems Related to Workforce Skills and Qualification. Journal of Competitiveness. 4(4), 50-66

KORMOS, J., 2004. Az esettanulmány, in: Kontráné Hegybíró E. - Kormos J. (szerk.) A nyelvtanuló: Sikerek, módszerek, stratégiák. 25- 30.

LE FEVRE, M. and KOLT, G. S., 2010. Occupational Stress: Are We All Talking About the Same Thing? New Zealand Journal of Employment Relations. 35(2), 16-27.

MARK, G., and SMITH, A., 2008. Stress models: A review and suggested new direction, Journal of Occupational Health Psychology 3, 11-144. 
MOORMAN ,R.H., 1991 Relationship between organizational justice and organizational citizenship behaviors: do fairness perceptions influence employee citizenship? Journal of Applied Psychology. 76(6), 845-855.

NOVOTNÝ, J., 2014 Personality of manager and managerial skills. Acta Oeconomica Universitatis Selye. 3(2), 123-129.

PISANTI, R., VAN DER DOEF, M., MAES, S., LAZZARI, D. and BERTINI, M., 2011. Job characteristics, organizational conditions, and distress/well-being among Italian and Dutch nurses: a cross-national comparison. International Journal of Nurs Studies. 48(7), 829-837.

REMI S., 2018. Dimensionality of intra-organizational conflict and the challenges for human resource management in small and medium scale enterprises in nigeria. Journal of Competitiveness. 10(1), 125-143.

SALAVECZ, G., 2011. A munkahelyi stressz és az egészség összefüggései hazai és nemzetközi viszonylatban, Budapest, 26.

SEILEROVÁ, M., 2019. The Consequences of Psychosocial Risks in the Workplace in Legal Context. Central European Journal of Labour Law and Personnel Management. 2(1), 47-60. doi: 10.33382/cejllpm.2019.02.04

SELYE, J., 1936. A syndrome produced by deverse noxious agents. Nature, 138, 32-45.

SELYE, J.,1956. The Stress of Life. McGraw-Hill, New York.

SELYE, J., 1976. Stressz Distressz Nélkül. Budapest: Akadémiai Kiadó

SIEGRIST,J., STARKE,D., CHANDOLA,T., GODIN,I., MARMOT,M., NIEDHAMMER,I. and PETER, R., 2004. The measurement of effort-reward imbalance at work: European comparisons. Social Science and Medicine 58(8), 1483-1499.

SMITH, A. and SMITH, H., 2017. A short questionnaire to measure wellbeing at work (Short-SWELL) and to examine the interaction between the employee and organisation, In: Charles, R \& Wilkinson, J. (eds). Contemporary Ergonomics and Human Factors. 200205. Chartered Institute of Ergonomics and Human Factors. ISBN: 978-1-5272-0762-2.

STEFKO, M., 2019. Notice for reasons of redundancy as a measure for discrimination on grounds of age. Central European Journal of Labour Law and Personnel Management, 1(1), 61-73. doi: 10.33382/cejllpm.2019.02.05

WILLIAMS, G.M., PENDLEBURY, H. and SMITH, A.P., 2017. Stress and Well-Being of Nurses: An Investigation Using the Demands-Resources - Individual Effects (DRIVE) Model and Well-Being Process Questionnaire (WPQ) J Depr Anxi. 1(1), 001. Jacobs Publishers

ZONI, S. and LUCCHINI, R. G., 2012. European Approaches to Work-Related Stress: A Critical Review on Risk Evaluation. 3, 43-9. 


\section{Contact address of the authors:}

Prof. Dr. Andrea Bencsik, CSc., J. Selye University, Faculty of Economics; University of Pannonia, Faculty of Business and Economics. E-mail: bencsika@ujs.sk; bencsik.andrea@gtk.uni-pannon.hu

Doc. Timea Juhasz, PhD., Budapest Business School, Faculty of International Management and Business. E-mail: juhasz.timi@hotmail.com

Doc. PhDr. Ing. Ladislav Mura, PhD., J. Selye University, Faculty of Economics. E-mail: ladislav.mura@gmail.com 